a modest premium for the herders. With joint commitment for wildlife conservation from communities and conservation agencies, this novel initiative by the Chushul community indicates that large carnivores, such as wolves and snow leopards, and agro-pastoralist communities can coexist.

AbHishek Ghoshal (D), Karma Sonam, Stanzin Namgall, Kulbhushansingh R. SurYaWAnshi and Charudutt Mishra Nature Conservation Foundation, Bengaluru, Karnataka, India, and Snow Leopard Trust, Seattle, USA

E-mail abhishek@ncf-india.org

MatTHIAS FieChTER Snow Leopard Trust, Seattle, USA

\section{A new 10-year conservation action plan for the western chimpanzee}

The Critically Endangered western chimpanzee Pan troglodytes verus, listed in Appendix 1 of CITES and in Class A of the African Convention on the Conservation of Nature and Natural Resources, is estimated to have undergone a $20 \%$ reduction in range and an $80 \%$ decline in abundance during 1990-2014 (Humle et al., 2016, IUCN Red List; Kühl et al., 2017, American Journal of Primatology, 79, e22681). This decline is linked to a multitude of threats, including poverty, civil conflict, human-wildlife disease transmission, an increasing human population, habitat loss and fragmentation, the illegal pet trade, extractive industries, infrastructure development, a lack of law enforcement and political instability. Although western chimpanzees are protected by national and international laws throughout their range, enforcement and government capacity is weak, and $>70 \%$ occur outside protected areas (http://apes.eva.mpg.de). The western chimpanzee is patchily distributed across eight countries (Côte d'Ivoire, Ghana, Guinea, GuineaBissau, Liberia, Mali, Senegal, Sierra Leone) and probably extinct in Benin, Burkina Faso and Togo (Humle et al., op. cit.). Their total population is estimated to be 35,000 (range 15,00o-65,00o; Kühl et al., op. cit.).

In 2003 a 10-year Regional Action Plan for West African Chimpanzees generated numerous conservation actions (Kormos et al., 2003, West African Chimpanzees. Status Survey and Conservation Action Plan, IUCN/SSC Primate Specialist Group). In light of the catastrophic decline of this subspecies, and emerging threats, Fauna \& Flora International (FFI), Liberia, teamed up with the Section on Great Apes of the IUCN Species Survival Commission Primate Specialist Group in 2016 to coordinate the development of a revised 10-year regional action plan for the western chimpanzee. The goal was to ensure that regional action for conservation of the subspecies targets emerging key threats and is coordinated amongst stakeholders and supported in the long term.
In December 2017 FFI and the Section on Great Apes organized a regional western chimpanzee action planning workshop in Monrovia, Liberia, convened by the Forestry Development Authority (Liberia's governmental body charged with protecting forests and wildlife). A technical committee of international experts provided support to plan the agenda using an open standards conservation action plan approach (http://cmp-openstandards.org). Over 60 experts and policy makers across the western chimpanzee range state countries attended, along with specialists in ape conservation. The workshop was funded by the US Fish and Wildlife Service, ARCUS Foundation, and the USAID West Africa Biodiversity Climate Change programme.

During the 5-day workshop participants (1) reviewed data on the status of and threats to the western chimpanzee, (2) analysed the regional context as a basis for developing updated region-wide strategies for western chimpanzee conservation, (3) obtained information on current research and conservation work carried out by stakeholders across the region, (4) identified the conditions necessary for the implementation of the regional conservation action plan, and (5) agreed on the next steps necessary for finalizing the regional conservation action plan for the western chimpanzee.

The new 10-year regional western chimpanzee action plan is expected to be finalized and disseminated in early 2019. Stakeholders remain committed to work towards a vision in which viable populations of western chimpanzees thrive in healthy ecosystems and coexist in harmony with human populations.

Michelle Klailova and Kathyrn Phillips Fauna \& Flora International, Cambridge, UK

E-mail michelle.klailova@fauna-flora.org

LIZ MACFIE Section on Great Apes, IUCN Species Survival Commission Primate Specialist Group

Mary Molokwu-Odozi Fauna \& Flora International, Monrovia, Liberia

\section{Can early- and mid-career conservationists get better career guidance?}

In July 2017 the Conservation Leadership Programme (CLP) and WWF's Russell E. Train Education for Nature Program (EFN) hosted a knowledge café at the Society for Conservation Biology's 28th International Congress for Conservation Biology in Cartagena, Colombia. The event brought together 20 participants from 10 countries (Brazil, China, Colombia, Madagascar, Malawi, Mexico, Tanzania, UK, USA and Viet Nam) for an open and participatory discussion, based on structured questions, to help understand the types and levels of support required for early and mid- 